\title{
Towards the Discourse of Islamic Philanthropy for Social Justice in Indonesia
}

\author{
Ariza Fuadi \\ Leiden University, the Netherlands. Rapenburg 70, 2311, EZ. \\ Email:rheiza_smart@yahoo.com
}

\begin{abstract}
The rapid development of Islamic philanthropic activism in Indonesia has drawn much attention among scholars, practitioners, and policy makers. It appears that efforts to promote Islamic philanthropic activism as a means of fostering social justice have been done by civil society organizations and the state's agencies. It can be seen partly in the motives and objectives of Islamic philanthropic associations, as well as regulations enacted by the state regarding the practice of Islamic philanthropy since independent era until nowadays. It suggests that the philanthropic culture in Muslim societies is no longer governed in a traditional way, or simply to relieve the poor. Instead, it is expected that through the culture of giving, poverty can be alleviated, and Islamic associations can provide long-term development projects. However, in reality, these efforts to promote social justice have been constrained by several factors, including social, economic and political factors, and therefore enduring and systematic efforts from the state's actors and civil society, to promote social justice are, still needed. Keywords: philanthropy, Islam, social justice.
\end{abstract}

\begin{abstract}
ABSTRAK
Perkembangan aktivisme filantropi Islam di Indonesia telah menyita perhatian para peneliti, praktisi dan pengambil kebijakan. Upaya untuk mempromosikan filantropi islam untuk tujuan memdorong terwujudkanya keadilan sosial telah dilakukan elemen masyarakat sipil maupun pemerintah. Hal ini dapat dilihat dari motivasi, tujuan, dan perundang-undangan dibuat Negara yang terkait dengan penerapan filantropi Islam sejak masa kemerdekaan hingga saat ini. Dewasa ini, gerakan-gerakan filantropi Islam tidak hanya dilakukan secara tradisional atau sekedar ditujukan membantu kaum miskin. Melainkan, melalui budaya filantropi inilah kemiskinan dapat dientaskan, dan program-program berjangka panjang bisa dibuat. Dalam faktanya, upaya mewujudkan keadilan sosial ini tidaklah mudah, karena banyak faktor, baik sosial, ekonomi maupun politik yang menjadi tantangannya. Untuk itu, upaya yang lebih sistematis dari Negara maupun masyrakat sipil masih sangat dibutuhkan untuk mempromosikan keadilan sosial.
\end{abstract}

Kata Kunci: filantropi, Islam, keadilan sosial.

\section{INTRODUCTION}

This study explores the discourse of Islamic philanthropy for social justice in Indonesia. It will examine the concept of social justice philanthropy as a basic foundation to the development of Islamic philanthropy in Indonesia. In this regard, the challenges to implement the concept of Islamic philanthropy for social justice in Indonesia are very significant to examine. In so doing, it will also explore the ways of people to the practice of 
Islamic philanthropy in Indonesia from the basic concept of personal and communal giving patterns.

Moreover, like other religions, Islam is against poverty and inequality in society. It is emphasized to the distributive justice towards the social class that Islam addressed. It stated in the Qur'ân that "wealth may not become fortune used by the rich among you" (Qur'ân 59:7). ${ }^{1}$ This command of distributive justice actually has been done by many Muslims in Indonesia, either personally or communally, to erase the poverty within the Muslims. However, this struggle has not showed positively that poverty in Indonesia has not been a major problem within the society.

I do believe that the unresolved poverty in Indonesia has been caused by the discrepancy between the core concepts and the ways they are commonly practiced. Traditional philanthropy is generally practiced on the grounds of direct giving services to fulfill the immediate and basic needs of the recipients by giving food, clothes and building shelter for the poor. Traditional philanthropy only focuses on service programs and avoids in the involvement of political issues. It is assumed that this practice of traditional philanthropy only helps the recipients for short term goals. Unlike traditional philanthropy, social justice philanthropy focuses on removing social injustice which is assumed to be the root of poverty and injustice. It observes the bridge due to associate the gap between the rich and the poor by mobilizing the resources of philanthropy in the society. To pursue its purposes, social justice philanthropy is organized by the collective action of social movement organizations. It can be said that there is a gap between traditional philanthropy and social justice philanthropy for all segments of the society. Therefore, it will analyze the challenges toward the practice of Islamic philanthropy for social justice in Indonesia. Also, how the Islamic philanthropy in Indonesia should be practiced due to the achievement of social prosperity and justice for the society will be examined.

All these issues will be described comprehensively taking into consideration of historical, socio-political and the process of the Islamic philanthropy practice in Indonesia. Through these approaches, this study will be seen obviously how the development of Islamic philanthropy in the past and the role of the government to resolved social justice on the grounds of Muslim philanthropy. Subsequently, the process of Islamic philanthropy in Indonesia will explain the ways of social justice philanthropy towards its challenges.

\section{ISLAMIC PHILANTHROPY IN INDONESIA AND ITS PROGRESS}

Historically, the practice of Islamic philanthropy has been implemented since the arrival of Islam in Indonesia. It was primarily practiced through the two institutions of the mosques and Islamic boarding schools (pesantrens) for the Muslim communities. These institutions were established in the $15^{\text {th }}$ century by Muslim communities in Java and Sumatra to develop the society on the grounds of education and religious teaching. Subsequently, the practice of Islamic philanthropy has significantly developed in the $19^{\text {th }}$ century with the raise of Islamic boarding schools and mosques in the archipelago due to support to the effort against Dutch occupation. ${ }^{2}$ At that time, the development of philanthropy was caused by the responses of the Muslim society in Indonesia to alienate 
from the Dutch Government. Therefore, Islamic philanthropy had grown as a financial resource to the development of Muslim communities.

During Dutch colonial rule, the awareness of Dutch Government to the used of Islamic philanthropy for political purpose made the practice of Islamic philanthropy had been regulated. On August 4, 1883, the Dutch Government issued the Bijblad No. 1892 to control zakât al-firi donations. In this Bijblad, zakât was mobilized by penghulu (religious figures) or the naib (deputy of local religious affairs in the mosque). Moreover, to weaken the resistance of the society that financed by zakât, the government prohibited the civil servant and local nobles to assist the management of zakât. This prohibition was stated in the Bijblad No 6200, dated February 28, 1905. ${ }^{3}$

It was similar to the rule of waqf that between 1905 and 1935, the Dutch Government issued four circulars by the Secretary to the Government (Circulaires van de Gouverments Secretaris). These four circular letters were in the Bijblad 1905 No. 6196, dated January 31, 1905 No. 435; Bijblad No. 125/3 Year 1931, dated June 4, 1931 No. 1361/A; Bijblad No. 13390 Year 1934, dated December 24, 1934 No. 3088/A; and Bijblad No. 13480, dated Mei 27, 1935 No. 1273/A. ${ }^{4}$ The issuance of these circulars was due to the purpose of Dutch Government to control over waqf activities by obliged the registration of waqf through the bupatis (regent) permission. Therefore, these circulars asked the bupatis to manage the waqf pertaining to the origins, the status as religious services whether through waqf or not. Yet, the bupatis were also requested to give a report about the use of the places of worship. The policies regarding Islam in the Japanese occupation were still implemented as in the Dutch Government. However, in this era, the implementation of Islamic law was relatively flexible and did not have much impact to the development of Islam in Indonesia. ${ }^{5}$

In the early period of Independent Indonesia, Office for Indigenous Affairs of the Dutch Government (Het Kantoor voor Inlandsche Zaken) was replaced by The Ministry of Religious Affairs (MORA) in January 1946. The task of this ministry was to ensure the freedom of the people to implement of their religious duties. The regulations concerning on waqf after that were remained in force as the regulation prior to the independence era until the issuance of the Government Regulation (PP, Peraturan Pemerintah). It was stated in the agrarian bill No. 5, 1960 article 49/3 that waqf is protected and regulated by Government Regulation. Therefore, the government issued a PP No. 28 Year 1977 concerning the regulation on the implementation of waqf in Indonesia. Moreover, in 2004, the government issued an enactment (Undang-undang) No 41 Year 2004 to control the development of potential waqf in Indonesia regarding to the tasks of the government upgrade the social prosperity within the society.

With regard to zakât practice, MORA issued a circular letter Surat Edaran No. A/ VVII/17367, dated December 8, 1951 concerning the role of the government on zakât. ${ }^{6}$ It was stated in this letter that the ministry would not interfere in zakât administration. MORA only had a responsibility to encourage people to pay zakât and assure the distribution of the zakât was carried out properly according to Islamic law. However, this responsibility of MORA was not pursued by 
the government to ensure that zakât was being paid or distributed properly. Hence, it shows that the government did not intend to establish the formal institution to manage zakât in Indonesia. The government more clearly left that zakât should be practice at an individual level.

However, on July 1967, Saifuddin Zuhri, a minister of Religious Affairs, proposed a draft of zakât law to the parliament or DPR-GR (Dewan Perwakilan Rakyat Gotong Royong, Mutual Assistance People's Council). The draft was also sent to the Ministry of Finance and the Ministry of Social Affairs for response. The Ministry of Finance suggested that the zakât management would be better regulated by the ministerial regulation rather than by a statute. Due to this suggestion, therefore, the parliament (DPR-GR) decided to not follow up this draft that was proposed by MORA.?

A year later, on July 1968, Muhammad Dachlan, the later Minister of Religious Affairs, issued a ministerial decree (Peraturan Menteri Agama, PMA No. 4/ 1968, dated July $15,1968)$ on the foundation of the official zakât agency (BAZ, Badan Amil Zakat). This decree stated that zakât would be operated by the governmental zakât committee at all villages and sub-districts all over the country. Three months later, however, Presiden Suharto annulled this ministerial regulation in his speech at Isrâ' Mi'râj (Prophet's Ascension) on October 26, 1968. President Suharto imposed the institution of zakât by taking responsibility for the collection and distribution of zakât on a personal basis as a private citizen. ${ }^{8}$ This offer of President Suharto was indicated that he only wanted to reject the changes of the Ministry of Religious Affairs on the zakât law. Additionally, he took personally to the collection and distribution of zakât since he was aware with the impression of the society that his regime was opposing Islam as religion as a result of the annulment of the regulation. President Suharto then issued a circular letter to all public offices and local governments to establish zakât agency in their workplace.

The operation of the zakât agency in the national level ruled by the President Suharto was operated only few years. It was due to the low response of the society that paid the zakât much lower than the number of Muslims in Indonesia. Unexpectedly, the number of zakât agencies gradually increased after the issuance of circular letter by Suharto. The emergence of the provincial zakât agency in Indonesia began in 1968 when the province of Jakarta founded a new institution responsible for collecting zakât. Several years later, other provinces followed suit, including the provinces of East Kalimantan (1972), West Sumatra (1973), West Java (1974), South Kalimantan (1974), South Sumatra (1975), Lampung (1975), Irian Jaya (1978), North Sulawesi (1985), and South Sulawesi (1985). Furthermore, in the early of 1990s, the new types of zakât agencies created by Muslim communities were established such as Dompet Dhuafa Republika, Pos Keadilan Peduli Umat. ${ }^{9}$

After the downfall of President Suharto, MORA found its momentum to propose a zakât law in Indonesia. The Enactment No. 38 concerning on zakât was approved under the Habibie Administration. However, in this enactment, there was a contest between Badan 'Âmil Zakât (BAZ, the government sponsored zakât agency) and Lembaga Âmil Zakât (LAZ, the privat zakât agency). The BAZ was provided fully arrangements, 
whereas the LAZ was not arranged at all in this enactment. It can be said that the government wanted to centralize the zakât formal administration into a single institution/ BAZ. Therefore, this zakât law is considered to be incomprehensive. Also, this law was only focused on the establishment of zakât agencies in the governmental level, rather focused on the nature of the zakât itself.

The efforts concerning the regulation of Islamic philanthropy in Indonesia have been struggled for many years. However, these efforts do not show the positive results on the regulation. Even though the regulations have been regulated, the regulations have not yet showed the fundamental orientation of an Islamic philanthropy which is directed towards social justice. Subsequently, the contradiction in the separation of the state and religion to accommodate Islamic aspirations was the other problem to the legislation of Islamic philanthropy. Hence, the development of Islamic philanthropy for social justice has faced the long-term challenges to its goals.

\section{SOCIAL JUSTICE PHILANTHROPY: A CRITIC TOWARDS TRADITIONAL PHI- LANTHROPY}

The term philanthropy derives from the Greek words phileo and anthropos. Phileo means love or the particular aspect of love. On the other hand, anthropos is defined as "humankind" in the widest sense of the word without discriminating every single human. ${ }^{10}$ The definition of philanthropy, therefore, can be defined as a desire of human to help others which is indicated by gives or acts of charity as a form of love to the mankind or public good. Considering its characteristic, philanthropy can be divided into two distinct classifications; traditional philanthropy and social justice philanthropy.

Traditional philanthropy is based on the charity of generosity. It is practiced, commonly, by providing direct social services such as giving food, clothes and building shelter for the poor. The concept of traditional philanthropy is generally on the grounds of direct giving services to fulfill the immediate and basic needs of the recipients. It means that traditional philanthropy only focuses on service programs and does not involve in political issues. Also, the practice of traditional philanthropy is considered to individual since this type of charity will be empowering and improving the status and prestige of the benefactor in the eyes of the public.

Different from traditional philanthropy, social justice philanthropy focuses on removing social injustice which is assumed to be the root of poverty and injustice. It observes the bridge due to associate the gap between the rich and the poor by mobilizing the resources of philanthropy in the society. To pursue its purposes, social justice philanthropy is organized by the collective action of social movement organizations. In Islam, the social movement organizations of philanthropy may be best represented by the position of 'âmil (caretakers of zakât). The 'âmil as intermediary between the poor and the rich can mobilize properly the resource of philanthropy in the society with the motives to maintain and develop the future of the society.

Social justice and traditional philanthropy is often articulated as "advocacy versus services” discourse. Social justice strengthens on the organizations which are effecting policy 
changes in the political issues including human rights, democracy, and justice to solve social programs. ${ }^{11}$ This kind of philanthropy emphasizes on accommodating people to resolve their own problem. The social justice philanthropic institutions focused on the empowerment of financial donation, either individual or collective, to the long-term goals of productive activities instead of consumptive purposes only. To achieve this goal, the activists of social justice philanthropy seriously assist the receivers to improve their quality of life. Therefore, the receivers in the future are expected to be independent from the helps of the other.

While traditional philanthropy on the other hand takes the form of direct giving to the service programs or providing service activities for short-terms purposes. Related to this concept, Sami Hasan stated in his research paper by quoting Caliph Umar bin AlKhattab that "If you give zakât, enrich the recipients". Many faqihs thus suggest that it would be better to give enough zakât by pulling the person out of poverty instead of giving zakât that does not bring a long term economic benefit for the recipient. ${ }^{12}$ It is similar to the axiomatic "give a man a fish, you feed him for a day; teach a man to fish, you feed him for a lifetime." In this context, traditional philanthropy only helps poor people on the immediate needs rather than bring them out from the poverty. It means that it is better to implement the practice of philanthropy on the grounds of social justice instead of traditional. The activists of social justice philanthropy argue that traditional philanthropy is not effective to eliminate the poverty and develop the society. Traditional philanthropy even is considered creating dependency of the poor people with this activity.

Social justice philanthropy is orienting its aims through institutional and systematic change in which the resources are collected and distributed towards the activities that will support social movement. The principals of social justice philanthropy engage the way to improve rights and duties in the basic institutions of society and appropriately distribute the benefits and problems through the social organization, advocacy and public education. ${ }^{13}$ Social justice philanthropy tries to solve social problems by attacking the roots of poverty problem in the society. Therefore, the fundamental expression of social justice philanthropy is addressing issues of social justice with the broader goals and managed by institutions.

It is quite relevant today to promote the idea of social justice philanthropy in Indonesia. The reasons are; first, the practice of social justice philanthropy should be in order to empower the people and community. This aim will be possible if the practitioners of the philanthropy are able to increase their competence and professionalism to manage the huge financial potential. Second, the traditional philanthropy providing social service for a short-term is inclined no longer sufficient to resolve the complex problem of Muslim community. And the last, Qur'ânic verses strongly encourage people to initiate social justice in the society that is given in the concept of 'adl, qis, and mîzân. ${ }^{14}$

\section{THE CHALLENGES OF ISLAMIC PHILAN- THROPY FOR SOCIAL JUSTICE IN INDO- NESIA}

The concept of social justice philanthropy is not a new term in Indonesia. It has actually been practiced by many Indonesia's philan- 
thropic institution. They usually implement this concept through many programmes such as anti-corruption, funding research, publishing journals and academic conferences, advocating for healthy food, working on environmental and the likes. Through this concept, it is expected that poverty in Indonesia can be resolved as the purposes of philanthropy. Also, the implementation of traditional philanthropy is believed cannot resolve the problem of poverty in the society since it only helps the poor for a short-term goal. The activists of social justice philanthropy argue that poverty is happened since there is an injustice in the society. Hence, the concept of social justice philanthropy concerns to promote social justice to resolve the problem of poverty in the society. The social justice philanthropic institutions focused on the empowerment of financial donation, either individual or collective, to the long-term goals of productive activities instead of consumptive purposes only. To achieve this goal, the activists of social justice philanthropy seriously assist the receivers to improve their quality of life. Therefore, the receivers in the future are expected to be independent from the helps of the other.

However, it should be noticed that social justice philanthropy with its efficient, purpose, professional organization, not necessarily remains social justice philanthropy. In its practice, social justice philanthropy generally has not totally directed towards social justice in the context of social change. It may sometimes remain traditional philanthropy since it rather addresses injustice. In much of the Muslim world traditional philanthropy is most practiced instead of social justice philanthropy.

This condition is made worse by the fact that the financial allocation for the philanthropy in Indonesia is generally still used very little to support social change in the society. A research done by CSRC (Center for the Study of Religion and Culture) UIN Syarif Hidayatullah Jakarta showed that the Indonesian Muslim mostly donates Islamic philanthropy to the religious activities in the mosque. The motive to practice Islamic philanthropy for social justice has not been seen as an important aspect due the understanding of the society to practice Islamic philanthropy as a religious purpose merely. ${ }^{15}$ The realization for Islamic philanthropy for social justice has faced some challenges in Indonesia. Methodologically the outcome from the implementation of philanthropy for social justice is still difficult to measure in the context of advocacy or policy research. ${ }^{16}$ It indicates that philanthropic institutions in Indonesia have a poor management to create social justice philanthropy. A well management, whereas, is a primary resource to the practice of Islamic philanthropy to create social justice in the society. Generally, the managers of philanthropic institutions only work for half-time instead of full-time working on the basis of voluntary working. With this basis, the activists of Islamic philanthropic institutions will be inclined to be unprofessional to increase productivity within philanthropic organizations. Islamic philanthropic institutions will only have functioned for the central of consumption rather than production. ${ }^{17}$ The condition of Islamic philanthropic institutions makes the purpose of social justice philanthropy difficult to achieve.

Furthermore, being involved in the political practice will bring the Islamic philanthropic institutions to the complicated problem. It is due to the effect of the political 
practice that sometimes will cause to a conflict in political issues for the public policy. Even, the conflict in the political issues will sometimes threat the existence of philanthropic institutions itself. Therefore, the Islamic philanthropic institutions in Indonesia usually prefer to keep away from political issues and avoid the controversy within the society. The other reason is that economically to promote social justice philanthropy is needed much costs for the activities such as advocacy, research and the likes. Also, in the developing countries, when the poverty increases, generally the philanthropic institutions focus on the direct service to help the poor for their basic needs. ${ }^{18}$ In this condition, the activists of Islamic philanthropic institutions should have the creativeness to implement philanthropy.

It is similar to what Helmut K. Anheier and Diana Leat that propose creative philanthropy, as quoted by Hilman Latief, to establish and implement philanthropy on the grounds of philanthropic activities. According to them, creative philanthropy can resolve the problem of poverty in the society through philanthropic activities that elaborated with the other concept of philanthropy. ${ }^{19}$ Hence, the concept of social justice philanthropy should be understood not only to advocating the public policy for social change, but also as a service for the poor. In the context of social change, principally philanthropy donation either individual or collective should be able to resolve the problem of poverty for short term and long term needs.

In order to reach the goal of social justice philanthropy that empowering the people for short term and long term goals, revitalization of Islamic philanthropic institutions is a matter of natural and should be directed towards a transformation from traditional into social justice philanthropy. However, this transformation should not leave the concept of traditional philanthropy in order to fulfill the social service immediately for the poor people. This means that Islamic philanthropic institutions have to focus on social service for the poor and consider to the causes of social injustice in the society as a kind of advocating to the social change.

In the Muslim societies, moreover, the practices of social justice philanthropy are very much related to their understanding of religious doctrine. This doctrine will be legitimated by the believers based on their view in the context of their way to live. ${ }^{20}$ Although in the Qur'ân has clearly explained the basic religious texts on the social justice, however, it only provides the basic guidelines of social relationships and advice for different human actions, social responsibilities, and solutions to social problems. ${ }^{21}$ Therefore, the attitude towards philanthropic doctrine must be reinterpreted in order to make the message of the Qur'ânic texts relevant in the modern context. This effort should consider on the fundamental ideas and purposes of philanthropy in Islam for the principals of social justice that clearly explained in the Qur'ân.

Reinterpretation of the Qur'ânic texts in the field for social justice should be addressed a number of issues. First, the division between religious orientation and social responsibility should be avoided in Islam. It is to promote the concept of social justice in Islam that not only focuses on religious but also social orientation. Second, the culture of Islamic philanthropy that being unorganized and individually should be stimulate to being organized to maintain the philanthropic 
mobilization of funds appropriately. Another issue, the 'amil needs to become more active, professional and visionary in carrying out the tasks. The next issue, the definition of the eight asnâf should be re-examined by means of analogy (qiyâs) or by other legal means. The last issue, revisit the kinds of wealth that should be subjected to zakât donations. ${ }^{22}$ Through these theological criteria of issues, the development of Islamic philanthropy for social justice in Indonesia will become more effective towards social change on the grounds of social service and advocacy.

\section{CONCLUSION}

The development of Islamic philanthropy has indicated that Muslims in Indonesia give a great attention to this practice. It can be seen from the motivations, purposes, and the regulations related to the implementation of Islamic philanthropy that rapidly grew within the society. At first, Islamic philanthropy that primarily practiced through two institutions of mosques and Islamic boarding schools was only used to upgrade the religious teaching and education of Muslims in Indonesia. In its development, when the era of Dutch occupation to Indonesia, Islamic philanthropy was also oriented to support the efforts against Dutch occupation. Moreover, after the independence era, the regulations of Islamic philanthropy in Indonesia have always been improved appropriately with the Indonesian culture in order to achieve its goals to resolve the primarily problem of poverty. Therefore, it is not exaggerating to say that Islamic philanthropy have a significant role within the society.

Islamic philanthropy in the recent era has not only been functioned traditionally to resolve the problem of poverty for short-term goals. It has also been focused on the resolving problem of poverty for long-term goals on the grounds of social justice philanthropy. Many activists of social justice philanthropy even argue that traditional philanthropy cannot resolve the problem of poverty. However, to practice of social justice philanthropy is not a simple matter that needs a great attention and long effort.

Moreover, the concept and practice of Islamic philanthropy for social justice has its own shortages. It is difficult in Indonesia to implement social justice philanthropy without consider to traditional philanthropy as a service for the poor. Indonesia as a developing country, the practice of Islamic philanthropy cannot focus on the one concept of traditional or social justice philanthropy merely. It should be recognized that between two concepts will complement one and another on its practice of Islamic philanthropy. The concept of traditional philanthropy will employ the social service for shortterm goals as a fulfillment to the basic need of the poor. The existence of orphanage, nursing home and the likes as a kind of social service is also still very important to be implemented in Indonesia. It will help and protect those who are powerless. While the concept of social justice philanthropy will work on the advocating programs that directed to the more autonomous future of the poor people as a kind of advocating to the social change within the society.

\section{ENDNOTES}

1 Muhammad Muhsin Khan and Muhammad Taqi-ud-Din Al-Hilali, Interpretation of the Meanings of the Noble Qur'an (Riyadh: Darussalam, 2001), p. 1089.

2 Azyumardi Azra, "Diskursus Filantropi Islam dan Civil Society" in Idris Thaha (ed.), Berderma untuk Semua: Wacana dan Praktik Filantropi Islam, (Jakarta: Penerbit TERAJU, 2003), p. xxvi. 
3 Uswatun Hasanah, "Potret Filantropi Islam di Indonesia" in Idris Thaha (ed.), Berderma untuk Semua: Wacana dan Praktik Filantropi Islam, (Jakarta: Penerbit TERAJU, 2003), p. 211.

4 Suparman Usman, Hukum Perwakafan di Indonesia, (Kudus: Darul Ulum Pres, 1994), pp. 50-51.

5 Chaidar S. Bamualim, "Islamic Philanthropy in Indonesia: Trends and Challenges towards Social Justice" in Kultur: The Indonesian Journal for Muslim Cultures, Vol 4. No. 1 (Jakarta: CSRC, 2009), p. 77.

6 Arskal Salim, The Shift in Zakat Practice in Indonesia: From Piety to an Islamic Socio-Political-Economic System, (Thailand: Silkworm Books, 2008), p. 28.

7 Arskal Salim, "The Influential Legacy of Dutch Islamic Policy on the Formation of Zakat (Alms) Law in Modern Indonesia" in The Pacific Rim Law and Policy Journal, Vol. 15 No. 3 (Washington: The University of Washington School of Law, 2006), pp. 694-695.

8 Arskal Salim, "The Influential Legacy of Dutch Islamic Policy," p. 695.

9 Arskal Salim, Challenging the Secular State: The Islamization of Law in Modern Indonesia, (Honolulu: University of Hawai Press, 2008), p. 125.

10 Sulek Marty, "On the Classical Meaning of Philanthropia", Nonprofit and Voluntary Sector Quarterly, Vol. 39, No. 3 (SAGE Publications, June 2010), p. 386.

11 Andy Agung Prihatna, "Philanthropy and Social Justice in Indonesia", in Chaider S, Bamualim, Cheyne Scout, Dick van der Miej, Irfan Abubakar (Eds), Islamic Philanthropy and Social Development in Contemporary Indonesia, (Jakarta: The Ford Foundation and Center for the Study of Religion and Culture (CSRC), 2006) p. 6.

12 Sami Hasan, Muslim Philanthropy and Social Security: Prospects, Practices, and Pitfalls, A paper presented at the $6^{\text {th }}$ ISTR Biennial Conference held in Bangkok, 9-12 July 2006, p. 4.

13 Sami Hasan, "Islamic Concept of Social Justice: Its Possible Contribution to Ensuring Harmony and Peaceful Coexistence in A Globalised World", in Macquarie Law Journal, Vol 7, (Sydney: Macquarie University, 2007), p. 168.

14 Chaidar S. Bamualim, "Islamic Philanthropy in Indonesia", p. 81.

15 Irvan Abu Bakar and Chaider S. Bamualim (eds.), Filantropi Islam dan Keadilan Sosial (Jakarta: CSRC, 2006), p. 188-191.

16 Irvan Abu Bakar and Chaider S. Bamualim (eds.), Filantropi Islam, p. 34.

17 Chaidar S. Bamualim, "Islamic Philanthropy in Indonesia", p. 85.

18 Irvan Abu Bakar and Chaider S. Bamualim (eds.), Filantropi Islam, p. 34.

19 Hilman Latief, Melayani Umat: Filantropi Islam dan Ideologi Kesejahteraan Kaum Modernis, (Jakarta:
Gramedia, 2010), p. 22.

20 Chaidar S. Bamualim, "Islamic Philanthropy in Indonesia", p. 86.

21 Samiul Hasan, Philanthropy and Social Justice in Islam: Principle, Prospect, and Practices, (Kuala Lumpur: A.S. Noordeen, 2007), p. 69.

22 Chaidar S. Bamualim, "Islamic Philanthropy in Indonesia", p. 86-87.

\section{BIBLIOGRAPHY}

Abu Bakar, Irvan and Bamualim, Chaider S, (eds.). 2006. Filantropi Islam dan Keadilan Sosial, Jakarta: CSRC.

Ahmed An-Na'im, Abdullahi and Mohamed Abdel Halim, Asma, "Rights-Based Approach to Philanthropy for Social Justice in Islamic Societies" in Kultur: The Indonesian Journal for Muslim Cultures, Vol 4. No. 1, Jakarta: CSRC, 2009.

Azra, Azyumardi. 2003. "Diskursus Filantropi Islam dan Civil Society" in Idris Thaha (ed.), Berderma untuk Semua: Wacana dan Praktik Filantropi Islam, Jakarta: Penerbit TERAJU.

Bamualim, Chaidar S. 2009. "Islamic Philanthropy in Indonesia: Trends and Challenges towards Social Justice" in Kultur: The Indonesian Journal for Muslim Cultures, Vol 4. No. 1 Jakarta: CSRC.

Hasan, Sami. 2007. "Islamic Concept of Social Justice: Its Possible Contribution to Ensuring Harmony and Peaceful Coexistence in A Globalised World", in Macquarie Law Journal, Vol 7, Sydney: Macquarie University.

2006. Muslim Philanthropy and Social Security: Prospects, Practices, and Pitfalls, A paper presented at the $6^{\text {th }}$ ISTR Biennial Conference held in Bangkok, 9-12 July.

-, 2007. Philanthropy and Social Justice in Islam: Principle, Prospect, and Practices, Kuala Lumpur: A.S. Noordeen.

Hasanah, Uswatun, 2003. "Potret Filantropi Islam di Indonesia" in Idris Thaha (ed.), Berderma untuk Semua: Wacana dan Praktik Filantropi Islam, Jakarta: TERAJU.

Latief, Hilman. 2010. Melayani Umat: Filantropi Islam dan Ideologi Kesejahteraan Kaum Modernis, Jakarta: Gramedia.

Muhsin Khan, Muhammad and Taqi-ud-Din Al-Hilali, Muhammad. 2001. Interpretation of the Meanings of the Noble Qur'ân, Riyadh: Darussalam.

Prihatna, Andi Agung. 2006. "Philanthropy and Social Justice in Indonesia", in Chaider S. Bamualim, Cheyne Scott, Dick van der Meij, and Irfan Abubakar (eds.), Islamic Philanthropy and Social Development in Contemporary Indonesia, Jakarta: The Ford Foundation and Center for the Study of Religion and Culture (CSRC).

Salim, Arskal. 2006. "The Influential Legacy of Dutch Islamic Policy on the Formation of Zakât (Alms) Law in 
Modern Indonesia" in The Pacific Rim Law and Policy Journal, Vol. 15 No. 3, pp. 694-695.

2008. Challenging the Secular State: The Islamization of Law in Modern Indonesia, Honolulu: University of Hawai'i Press.

, 2008. The Shift in Zakât Practice in Indonesia: From Piety to an Islamic Socio-PoliticalEconomic System, Thailand: Silkworm Books.

Sulek, Marty. 2010. "On the Classical Meaning of Philanthropia", in Nonprofit and Voluntary Sector Quarterly, Vol 39, No. 3, SAGE Publications.

Usman, Suparman. 1994. Hukum Perwakafan di Indonesia, Kudus: Darul Ulum Pres. 